\title{
Michigan Journal of Sustainability
}

\section{Beyond Green Consumerism: Uncovering the Motivations of Green Citizenship}

MEAGHAN GUCKIAN

Department of Environmental Conservation, University of Massachusetts, Amherst, MA 01003

RAYMOND DE YOUNG

School of Natural Resources and Environment, University of Michigan, Ann Arbor, MI 48109

SPENCER HARBO

School of Natural Resources and Environment, University of Michigan, Ann Arbor, MI 48109

Volume 5, Issue 1

http://dx.doi.org/10.3998/mjs.12333712.0005.105

\section{ABSTRACT}

Individual behavior change is a necessary condition for making a positive societal transition to a resource-constrained future. Because we live on a planet with finite resources, behavior change interventions need to move beyond creating "green consumers" and instead foster and support "green citizens." Green consumerism has proven largely ineffective in curbing collective rates of consumption; despite improved efficiencies and green-and-lean social norms and policies, society's aggregate resource and energy usage continues to climb. There is an urgent need to promote agency and self-sufficiency with regard to individual conservation behaviors, while simultaneously promoting mindfulness of collective impacts on the planet. Based on 
an analysis of results from a community-based survey $(\mathrm{N}=223)$ conducted in Southeastern Michigan, this article develops a profile of a green citizen and documents how it differs from that of a green consumer. Characteristics of green citizenship go beyond pro-environmental knowledge and attitudes and thoughtful consumer behavior. Green citizens hold a distinct psychological motivation from the frugal use of resources and demonstrate a connection to nature, compared to green consumers, who are motivated by helping others and identify with pro-environmental attitudes. The emerging profile of green citizens and their associated behaviors suggest a need for policy and community action initiatives that dramatically differ from those currently aimed at promoting green consumerism. A reframing of environmental programs, away from consumerism and toward citizenship, may prove challenging. Deeply embedded in most current environmental efforts is a view of people as consumers who can be manipulated to make the correct decisions. The data reported here uncover mindful actors with power and agency. The article concludes by offering recommendations for policymakers, educators, and organizers to foster durable change in our communities.

\section{Introduction}

The environmental challenges we face today, including rising sea levels, increasing global temperature, deforestation, and the declining availability of natural resources, are the result of human consumption. Our aggregated impact on the environment is the product of three main pathways: affluence (consumption), population, and technology (Dietz, Rosa, and York 2007; Ehrlich and Holdren 1971). As global population continues to grow and technological advances make consumption easier and more convenient, our depletion of the planet's resources and release of greenhouse gases puts an increasingly significant strain on the planet. The observed relationship between consumption and greenhouse gas emissions (Cohen, Lenzen, and Scaefffer, 2005; Munksgaard et al. 2005) makes it clear that we must change how we consume resources if we are to transition to a more sustainable society.

The dominant response to this problem is promotion of a green economic transition. This market-based paradigm suggests that by greening the materials and services of the world's economy, industrial society's current levels of consumption can remain unchanged while we marginally redirect growth and mitigate environmental impact. In spite of society's intergenerational environmental dilemma, the projected role of the individual remains anchored to that which it has been for decades- the 
sovereign consumer whose primary domain is the marketplace. Shifting to greener consumption patterns is a necessary behavioral response but alone is suggested to be insufficient to effectively address the challenges presented by climate change and declining natural resource availability (Dietz, Rosa, and York 2007; Jackson 2009). Thus, a broader range of behavioral responses is needed, something beyond merely redirecting individuals' consumer choices (Clayton et al., 2016).

Fortunately, research documents that individuals support alternative pathways to sustainability, rooted in reduced consumption and the belief that a simpler life will improve societal and individual wellbeing (De Young 1990, 1996; Brown and Kasser 2005; Markowitz and Bowerman 2014). Thus, while continuing to channel individuals' behavioral responses through market-based patterns of consumption, we must also foster broader behavioral engagement that extends beyond individuals' prescribed role as green consumers. In this paper, we examine an alternative societal role-green citizenship — and the extent to which it relates to and is distinct from green consumerism. We also discuss how the green citizen might move beyond the political action described in the notion of the 'ecological citizen' to include everyday behaviors.

\section{Green Consumption and Environmental Behavior}

The association between consumption and greenhouse gas emissions has been instrumental in arguing that individuals should be employed as the principal agentsof-change. Indeed, a considerable amount of research has underscored how and to what extent various social-psychological and contextual factors shape behavior (Ajzen 1991; Bamberg and Schmidt 2003; Fishbein and Ajzen 1977; Kaplan and Kaplan 2009; Stern 2000). In turn, researchers have created tools useful in maintaining and/or increasing patterns of green consumption, while governments have enacted policies, such as taxes on plastic bag use, to support the proliferation of it (Abrahamse et al. 2005; De Young 1993; Pike, Doppelt and Herr 2010; Thomas, Poortinga, and Sautkina, 2016). These approaches are not surprising given industrial society's fondness for strategies that leave intact the assumed links between consumerism and growth, wealth, and status (Kasser et al. 2007; Kasser and Ryan 1996; Weiss 1969). Yet, the shortcomings of green consumption are many.

The primary issue with prompting individuals to assume the role of green consumers centers on the narrow pathway through which change is directed: steer consumption to greener pastures and properly dispose of waste. Commonly targeted behaviors including recycling, reusable bags, and alternative product use (e.g, ef- 
ficient light bulbs, green household products; Gilg, Barr, and Ford 2005) enable individuals to consume at or above equivalent rates, while only marginally reducing ecological impacts. It is a truism that any form of consumption is directly and indirectly associated with the use of energy and $\mathrm{CO}_{2}$ emissions. Alfredsson (2004) found that adopting green consumption behaviors with regard to food, travel, and other household behaviors without decreasing overall consumption would not make a large difference across scales.

The proclivity to focus on green consumption has been met with criticism (Shove, 2010), given that these behaviors often constitute less environmental impact (Gardner and Stern, 1996), are regulated to the private domain, and are often not economically viable options for low-income populations (Kollmuss and Agyeman, 2002). Despite the rise of local policy to support sustainable consumption (e.g., Thomas et al., 2016), leaders in the field of conservation psychology have highlighted the need to examine and encourage the uptake of public-sphere behaviors including community engagement, lobbying, and voting to signal and shift support for larger-scale, more impactful action (Clayton et al., 2016; e.g., Schuitema, Steg, and Forward, 2010). Additionally, others have noted that narrowly focusing on consumption behaviors may also deprive individuals of intrinsic benefits embedded within alternative pathways to engagement (De Young 1996). Empirical research reveals that individuals find the pursuit of competence (e.g., learning new skills), frugality (e.g., pursuing resourcefulness), community participation and opportunities for meaningful action to be intrinsically satisfying and effective motivators of long-term environmental stewardship (De Young 1996; Ryan and Grese 2005; Ryan, Kaplan, and Grese 2001).

Despite these shortcomings, the prevailing role for individuals in thwarting ecological disaster is almost entirely that of a green consumer. This is troublesome provided research suggesting that the societal role individuals occupy in a given context influences their decision-making and can perpetuate behavioral patterns when decisions are made that align with that role (Cornelissen et al. 2013; March 1994; Truelove et al. 2014; Weber, Aimes, and Blais 2005; Weber and Lindemann 2007). Indeed, if individuals continue to be cast only as consumers, they are more likely to respond to environmental issues according to the expectations and opportunities afforded by that role. Provided that the environmental challenges lying ahead necessitate members and sectors of society (e.g., government, industry) to accept far broader responsibilities and behavioral responses - those beyond consumerism-we need to envision and investigate alternative roles. 


\section{Green and Ecological Citizenship}

The notion of green citizenship provides a framework for re-conceptualizing individuals' social role with respect to reducing consumption. Although the idea of green citizenship did not emerge until recently (De Young 2014), we draw on the related, largely theoretically based concept of 'ecological citizenship' and explore how certain elements of this concept may inform green citizenship.

British political theorist Andrew Dobson's conceptualization of ecological citizenship extended the rising discourse in political theory on 'interconnectedness,' which stated that individuals' obligation and responsibilities as citizens should extend beyond the nation-state and include non-human entities and future generations (Christoff 1996; Dean 2001; Dobson 2003; Engel 1998; van Steenbergen 1994). Dobson's theory of ecological citizenship operates according to the ecological footprint concept and posits that every person should occupy an equitable amount of ecological space, limited by the availability of resources and the earth's carrying capacity (Dobson 2003). Given that the distribution of ecological space across the world's developed and developing nations is disproportionately unjust, the primary responsibility charged to ecological citizens, particularly those residing in developed industrial societies, is to reduce the size of their ecological footprint (Dobson 2003; Dobson 2006). According to Dobson, the principal features of ecological citizenship are that it is non-territorial, non-reciprocal, non-contractual, and built on the virtues of justice and equity. Perhaps most intriguing is the behavioral extension of citizenship into the private sphere, which suggests that ecological citizens consider not only the customary political or public implications of citizenship (e.g., voting), but also how their private behaviors shape their public impact (e.g., consumption choices; Dobson 2003).

Empirical research has systematically examined ecological citizenship and the extent to which members of society hold the values and beliefs Dobson highlights (Horton 2005; Jagers 2009; Jagers and Matti 2010; Jagers, Martinsson, and Matti 2014; Seyfang 2006; Wolf, Brown, and Conway 2009). Jagers and Matti (2010) sought to measure ecological citizenship in a Swedish population, while Wolf, Brown, and Conway (2009) explored how Canadian citizens' perceptions of personal responsibility influenced their actions as voters and consumers. Yet many of the studies cited here do not encompass the broad spectrum of everyday behaviors envisioned by green citizenship. Instead, private sphere behaviors are routinely measured by individuals' willingness to purchase green products and reduce household waste, while public sphere behaviors involve support for environmental policies, 
including increased taxes on petrol and non eco-labeled products (Jagers 2009; Jagers, Martinsson, and Matti 2014; Wolf, Brown, and Conway 2009).

\section{Profiling the Green Citizen}

Green citizenship refers to the breadth of environmental behaviors individuals navigate and can engage in during common, everyday life patterns that span both the private and public sphere. Although pro-environmental individuals, identified through their green consumer behavior, have been described in detail with respect to personality traits (Markowitz et al. 2012), demographics (Davidson and Freudenburg 1996; Thogersen and Olander 2006), and sociological constructs (Cialdini 2003), only limited research has examined the notion of green citizenship (De Young 1996; Guckian et al. 2017; Hamilton et al. 2017). Thus, the goal of the research presented here is to explore the relations of broad social-psychological factors to the performance of green citizenship behaviors compared to green consumer actions. To accomplish this, the study drew from relevant literature characterizing pro-environmental behavior and motivations, including attitudes toward nature (Dunlap et al. 2000), ascriptions of responsibility (Harland et al. 1999; Stern et al. 1999), prosociality (Schultz 2001; Stern et al. 1995), and connectedness to nature (Mayer and Frantz 2004; Nisbet, Zelenski, and Murphy 2009). It seems likely that the underlying values, motives, and perspectives of green citizens will expand beyond conventional understanding of the pro-environmental individual, whose actions are often measured in terms of their consumer purchases and/or recycling habits (e.g., Bamberg and Moser 2007).

One of the ways in which green citizen behavior may move beyond the realm of green consumerism is through the act of sharing resources, a practice that has been common throughout human history but is less common in the modern industrial age. Resource sharing can refer to the act of sharing skills, services, or items with others. The notion of a sharing economy has grown in recent years due, in part, to technological advancements that have made coordinating the sharing goods and services easy through online platforms (Hamari, Sjöklint, and Ukkonen 2015). There has been some debate within the academic community about the environmental benefits of the sharing economy. Some researchers suggest that the sharing economy is an inherently more sustainable market-based system than standard capitalism because it reduces consumption by encouraging the collaborative management of resources instead of individualized ownership and use (Heinrichs 2013). Moreover, within cities, the sharing economy is argued to lead to increased community engagement 
and connectedness (Harmaala 2015), potentially replacing object-focused hedonic wellbeing with a more purposeful and goal-oriented eudemonic satisfaction. However, other researchers believe that the sharing economy has been appropriated by the corporate sector, where it has been reframed as a commercial opportunity instead of an opportunity for creating a sustainable society (Martin 2016). However, in the context of green citizenship, it is important to understand the extent to which individuals are motivated to share resources as a means of addressing environmental problems and responding to limits to growth.

Currently, behaviors like resource sharing are not those toward which members of industrial societies typically strive. Indeed, the more common set of motives guiding the behavior of citizens in industrial societies seem unlikely to initiate or sustain the behavior change that is needed. The need for the frugal use of resources, for instance, may be valued in the abstract by people and eventually be necessary for a community to thrive, yet very few individuals within developed societies presently practice frugality. In fact, this once-commonplace virtue (Nash 1998) has become much maligned and dismissed as old-fashioned. It seems likely that any motivation to be frugal is currently overwhelmed by the motivation to be comfortable, to be successful, or to better one's standard of living.

Some of the aforementioned literature suggests that green citizens may be motivated to engage in otherwise underappreciated behaviors, including the reuse and source reduction of materials, the sharing of resources, and community-based participation in green initiatives. Thus, in contrast to the traditional behaviors encouraged by green consumption within the private domain (e.g., post-consumption recycling, purchasing efficient light bulbs, organic food), we expect the behaviors of green citizens to include those within both the public and private domain. Private consumption actions might include those that encourage reduced consumption (e.g., frugality, resource sharing), while public behaviors might entail the participation in community programming. Additionally, given Dobson's description of ecological citizenship $(2003,2006)$, we suspect that green citizens' motivation may emerge from an ability to prospect the future, understand their place in the world (e.g., connectivity), and value equity and justice. Thus, we examined how and to what extent intrinsically motivating factors (De Young 1996), meaningful participation (Ryan, Kaplan, and Grese 2001; Ryan and Grese 2005; Kaplan and Kaplan 2009), future prospection (De Young 2014), and facets of ecological citizenship (Dobson 2003; Dobson 2006; Hayward 2006) related to the behaviors of green citizens through a survey of those working in environmental professions. 


\section{Method}

The literature reviewed above was used to create a survey instrument identical in both its online and paper format. The paper version of the survey instrument was distributed to community members at a community-based green fair in 2014 in Ann Arbor, Michigan. The online survey instrument was distributed to several environmental organizations with members in the US and abroad. These groups included the Association for Environmental Studies and Sciences (AESS, an organization serving interdisciplinary environmental programs), Colorado State University's Conservation Psychology email listserv, Division 34 of the American Psychological Association (which focuses on research and practice in the field of environmental, population, and conservation psychology), and the North East Environmental Studies group (NEES). Because of the professional affiliations of the sample, survey respondents are not representative of the broader population and are better described as potential early adopters of green citizenship behaviors. Nonetheless, the data reported below can help begin developing a profile of a green citizen. Table 1 provides the demographic characteristic of the survey respondents.

Table 1. Respondent characteristics

\begin{tabular}{lcrlrc}
\hline Gender $(n=158)$ & Frequency & $\%$ & Education $(n=160)$ & Frequency & $\%$ \\
\hline Male & 56 & 35.4 & Some high school - some college & 2 & 01.2 \\
Female & 102 & 64.6 & Four-year college degree & 19 & 11.9 \\
& & & Master's degree & 51 & 31.9 \\
& & & Doctoral or professional degree (JD, & 88 & 55.0 \\
& & & MD) & & \\
Age $(n=161)$ & Frequency & $\%$ & Profession $(n=159)$ & 74 & 46.5 \\
\hline $20-29$ & 28 & 17.4 & Academic & 11 & 06.9 \\
$30-39$ & 56 & 34.8 & Researcher & 43 & 27.0 \\
$40-49$ & 33 & 20.5 & Other professional & 26 & 16.4 \\
$50-59$ & 27 & 16.8 & Student & 5 & 03.1 \\
$60-79$ & 17 & 10.5 & Retired or unemployed & Frequency & $\%$ \\
Income $(n=156)$ & Frequency & $\%$ & Region $(n=152)$ & 62 & 40.8 \\
\hline Under $\$ 20,999$ & 13 & 08.3 & Northeastern US & 23 & 15.1 \\
$\$ 20,000-\$ 59,999$ & 45 & 28.9 & Southern US & 33 & 21.7 \\
$\$ 60,000-\$ 99,999$ & 51 & 32.7 & Midwestern US & 23 & 15.1 \\
$\$ 100,000$ and above & 47 & 30.1 & Western US & 11 & 07.2 \\
& & & Outside US & &
\end{tabular}




\section{Measures}

The survey instrument included measures of a number of independent, literaturederived constructs. These are outlined here, in brief, and discussed in detail in the text accompanying Tables 3 through 6 . Each of these tables document the results of the factor analysis described below; each table includes the individual survey instrument items organized into the factor-analysis-identified categories. Each category is give a unique name (then used throughout the remained of this paper), and each category's mean, standard deviation, and alpha value is reported.

A set of survey instrument items measured behavioral characteristics that differentiate green citizens from green consumers; the set included items that are consumer-centric as well as behaviors focused on reducing consumption. A broad range of environmental behaviors were included that spanned across the public and private domain (see Table 3 for survey items). The factor analysis extracted two independent categories of behavior: green consumerism and green citizenship. The survey instrument assessed and the factor analysis identified the respondents' consideration about the future and their intention to change behavior (See Table 4 for survey items). Intrinsic satisfactions, including those previously identified as being motivations for environmental stewardship behaviors (De Young 1996), were measured (see Table 5 for survey items). Lastly, items measuring attitudes about consumption-related environmental issues and feelings about one's connection to nature were included (see Table 6 for survey items). These latter measures are important to include as they may indicate the extent to which thinking about the environment and feeling connected to it may lead to the behaviors associated with green citizenship. Once the factor analysis identified the categories, the analysis proceeded to a second phase where stepwise linear regression was used to identify the significant predictors of the two behavior categories from among the demographic characteristics and psychological categories.

\section{Data Analysis}

Dimensional analysis was used in this study to examine the structure of each bank of items: behavior, prospecting the future, intrinsic satisfactions associated with a range of behaviors, pro-environmental attitudes, and connectedness to nature. All items used a five-point Likert rating scale. Some individual items were worded in the negative with their data reversed before analysis so that a score of five always indicates positive endorsement for an item. The procedure used to identify categories 
from among the items was a metric factor analysis program using principle component analysis and varimax rotation. Kaplan (1974) has suggested three criteria useful in interpreting the output from such programs. The criteria stipulate that any particular questionnaire item should be included in no more than one category, each category should "hang together" statistically, as indicated by Cronbach's coefficient of internal consistency, a (Cronbach 1951; Nunnally 1978), and the category should make sense, having face validity. The output of the factor analysis program was used to identify highly coherent and stable categories. Following the identification of these categories, new variables were constructed for each by calculating a respondent's average rating of the items that formed each category. This resulted in a single score on each category for each respondent. The results discussed in the text and reported in the tables refer to those relationships and predictions found to be statistically significant at the $\mathrm{p} \leq 0.05$ level (see Table 2 for correlations among study variables).

\section{Results}

\section{Green Citizens and Consumers}

Eighteen items measured behavioral characteristics of Green Citizens, including such items as, "Look for new ways to avoid waste" and "Repair items rather than buy new ones." Items related to Green Consumerism included "Choose 'green products' over conventional ones" and "Reduce packaging by buying in bulk." The factor analysis identified the two behavior categories shown in Table 3. The Green citizen and Green consumer categories are conceptually distinct; the items capture

Table 2. Pearson R correlations between independent and dependent study measures

\begin{tabular}{|c|c|c|c|c|c|c|c|c|}
\hline & $(1)$ & $(2)$ & (3) & $(4)$ & $(5)$ & (6) & (7) & (8) \\
\hline \multicolumn{9}{|l|}{ Green citizen (1) } \\
\hline Green consumer (2) & .401 & & & & & & & \\
\hline Intention to change (3) & .389 & .385 & & & & & & \\
\hline Need to change $(4)$ & .068 & .234 & .438 & & & & & \\
\hline Pro-environmental attitudes (5) & .311 & .425 & .524 & .277 & & & & \\
\hline Connected to nature (6) & .427 & .401 & .539 & .164 & .614 & & & \\
\hline ISAT-competence (7) & .618 & .263 & .408 & .135 & .315 & .444 & & \\
\hline ISAT-frugality (8) & .227 & .152 & .263 & .014 & .288 & .372 & .326 & \\
\hline ISAT-helping (9) & .370 & .293 & .410 & .273 & .228 & .348 & .408 & .359 \\
\hline
\end{tabular}

Note. ISAT is abbreviated for intrinsic satisfaction. Bolded values indicate significance of $p<.05$. 
Table 3. Green citizen and consumer categories

\begin{tabular}{lccc}
\hline Category names and items included * & Mean** & S.D. & Alpha \\
\hline Green citizen & 3.98 & .64 & .81 \\
$\quad$ Find ways to do things that don't rely on consuming & & & \\
Decrease the amount of things I buy & & & \\
Search for products that can be reused & & \\
Try to use things over and over & & \\
Look for new ways to avoid waste & & \\
Repair items rather than buy new ones & & \\
Sew clothes or wear used clothing & 3.91 & .71 \\
Green consumer & & \\
$\quad$ Choose "green products" over conventional ones & & \\
Buy local products & & \\
Seek out organic products & & \\
Purchase fair trade items & & \\
Look for items that are labeled as eco-friendly & & \\
\hline
\end{tabular}

Note. * Stem question was "Please indicate how often you do the following." The 5-point Likert scale ranged from $1=$ never to $5=$ very frequently.

** Means are not significantly different at $p \leq 0.05$.

*** Six items, including "Use alternate forms of transportation," "Select the most cost-effective products," "Express concern for the world we are leaving to future generations," "Engage in environmental events," "Reduce packaging by buying in bulk," and "Grow fruits or vegetables" failed to load at or above the set cut-off and were therefore not included in the composites $(>.40)$.

very different patterns of behavior, and the categories are correlated at only $\mathrm{r}=0.40$ $(p \leq 0.01)$, indicating a shared variance of only 16 percent. The respondents endorse both categories at a moderately high level.

\section{Prospecting the Future}

Being able to prospect the future is a much-needed skill for a society that will be spending the next century or more adapting to a disrupted climate or responding to a reduction in energy resources and material wellbeing (De Young 2014). This study identified two aspects of future prospection, one in the form of an intention to change and the other focused on accepting that personal behaviors will need to change (Table 4).

The Intention to change and Need to change categories are correlated at $\mathrm{r}=0.44$ $(\mathrm{p} \leq 0.001)$ indicating a shared variance of only 19 percent. It is possible that these categories reflect different stages of the process of change as outlined in the Stages of Change (Transtheoretical) model of behavior change (Prochaska and DiClemente 1982). The Need to change category may fall within the contemplation stage of that 
Table 4. Prospecting the future categories

\begin{tabular}{lccc}
\hline Category names and items included* & Mean** & S.D. & Alpha \\
\hline Intention to change & 4.08 & .72 & .83 \\
I will make major lifestyle changes to support future generations & & & \\
My actions reflect my hopes for the future & & \\
I want to restore the environment for future generations & & \\
I feel a growing obligation to improve the environment's health & & \\
I feel a moral responsibility to lower my ecological footprint & & \\
I take into account how my decisions may affect environment & & .86 & .60 \\
Need to change & & & \\
I need to examine my priorities more often & & & \\
It is clear that we soon will need to make major lifestyle changes & & & \\
I should spend more time helping my neighbors & & \\
\hline
\end{tabular}

* Stem question was "When thinking about the future, how much do the following items match your thoughts." The 5-point Likert scale ranged from $1=$ not at all to $5=$ a very great deal.

** Pairwise comparison of means is significantly different at $p \leq 0.001$.

model while the Intention to change category would seem aligned with the model's preparation stage.

\section{Intrinsic Satisfactions}

Previous research indicates that building competence, being resourceful, and participating with and/or helping others to create change intrinsically motivates people (De Young 1996). These motivations may be critical to make the individual-level changes that will be required to meet future environmental challenges. Three intrinsic satisfaction categories were identified by factor analysis: competence, frugality, and a pro-helping category that included items measuring satisfaction derived from sharing physical and social resources (Table 5).

There were statistically significant correlations ( $\mathrm{p} \leq 0.001)$ between the categories of Competence and Frugality $(\mathrm{r}=0.33,11$ percent shared variance), Competence and Helping $(\mathrm{r}=0.36,13$ percent shared variance), and Frugality and Helping $(\mathrm{r}=$ $0.41,17$ percent shared variance).

\section{Profile Categories}

Two categories that provide a profile of environmental responsibility were identified by the factor analysis (Table 6). The first, Pro-environmental attitude, is a frequently reported variable in conservation behavior research. When combined with other variables, 
Table 5. Intrinsic satisfaction categories

\begin{tabular}{|c|c|c|c|}
\hline Category names and items included $*$ & Mean** & S.D. & Alpha \\
\hline $\begin{array}{l}\text { Competence } \\
\text { Learning how to solve most problems I face } \\
\text { Knowing how to finish a task } \\
\text { Remaining competent at meeting life's challenges } \\
\text { Discovering new things that I'm good at doing } \\
\text { Being good at the things I need to do } \\
\text { Doing things that matter in the long run }\end{array}$ & 4.35 & .47 & .75 \\
\hline $\begin{array}{l}\text { Frugality } \\
\text { Finding ways to use things over and over } \\
\text { Repairing rather than throwing things away } \\
\text { Keeping something running long past its normal life } \\
\text { Finding ways to avoid waste }\end{array}$ & 4.12 & .68 & .82 \\
\hline $\begin{array}{l}\text { Helping } \\
\text { Seeing to it that my neighbors are well-fed/well-off } \\
\text { Sharing the household skills I have with others } \\
\text { Helping to make sense out of the world } \\
\text { Working to improve the well-being of others } \\
\text { Sharing the tools I own with neighbors }\end{array}$ & 3.59 & .72 & .72 \\
\hline
\end{tabular}

it is often found to be a predictor of environmental stewardship behaviors (Kollmuss and Agyeman 2002). The second category, Connected to nature measures the inclusion of nature in the conception of the self. This notion has been reported to be a predictor of environmentally responsible behaviors (Mayer and Frantz 2004; Nisbet, Zelenski and Murphy 2009). The Pro-environmental attitude and Connected to nature categories are correlated at $\mathrm{r}=0.61(\mathrm{p} \leq 0.001)$ indicating a shared variance of 38 percent.

\section{Regression Analysis}

The primary question being explored in this study is the degree to which green citizenship behavior might differ from that of the green consumer. Using the various categories reported above, stepwise linear regression analyses were performed to determine the predictors of the Green consumer and Green citizen behavior categories.

In fact, the regression results indicate that green consumerism and green citizenship do differ significantly in their respective predictors (Table 7). The Green consumer category is predicted by the respondent's pro-environmental attitudes and in- 
Table 6. Profile categories

\begin{tabular}{lccc}
\hline Category names and items included * & Mean** & S.D. & Alpha \\
\hline Pro-environmental attitude & 4.56 & .48 & .75 \\
Amount society consumes is major cause of environmental problems & & & \\
Humans are severely abusing the environment & & \\
Most of us consume far more than we need & & \\
My actions are driven by concern for the environment & 4.44 & .57 \\
Connected to nature & & \\
I feel strongly about keeping the place I live ecologically healthy & \\
I am curious to learn new ways to conserve resources & \\
I feel a strong attachment to nature \\
The more connected people are to nature, the better off society will be \\
* Stem questions for each of these banks were on a 5-point Likert scale of agreement from 1 = not at all true to \\
5 = very true.
\end{tabular}

Table 7. Stepwise regression models predicting behavior categories

\begin{tabular}{|c|c|c|c|c|c|c|}
\hline \multirow[b]{2}{*}{ GREEN CONSUMER BEHAVIOR } & \multicolumn{3}{|c|}{ Step 1} & \multicolumn{3}{|c|}{ Step 2} \\
\hline & $\mathrm{b}$ & $\mathrm{SE} \mathrm{b}$ & $\beta$ & $\mathrm{b}$ & SE b & $\beta$ \\
\hline Constant & 1.07 & .49 & & .66 & .49 & \\
\hline Pro-environmental attitude & .62 & .11 & $.43^{*}$ & .55 & .11 & $.38^{*}$ \\
\hline \multirow[t]{5}{*}{ Intrinsic satisfaction-Helping } & - & - & - & .20 & .07 & $.21^{* *}$ \\
\hline & & $F$ & $34.6^{*}$ & & $F$ & $22.1^{*}$ \\
\hline & & $R^{2}$ & .18 & & $R^{2}$ & .22 \\
\hline & & ed $R^{2}$ & .17 & & ted $R^{2}$ & .21 \\
\hline & \multicolumn{3}{|c|}{ Step 1} & \multicolumn{3}{|c|}{ Step 2} \\
\hline GREEN CITIZEN BEHAVIOR & b & SE b & $\beta$ & $\mathrm{b}$ & SE b & $\beta$ \\
\hline Constant & 1.61 & .25 & & .99 & .33 & \\
\hline Intrinsic satisfaction-Frugality & .58 & .06 & $.62^{*}$ & .50 & .06 & $.53^{*}$ \\
\hline \multirow[t]{4}{*}{ Connected to nature } & - & - & - & .21 & .08 & $.19^{* * *}$ \\
\hline & & $F$ & $96.8^{*}$ & & $F$ & $54.3^{*}$ \\
\hline & & $R^{2}$ & .38 & & $R^{2}$ & .41 \\
\hline & \multicolumn{2}{|c|}{ Adjusted $R^{2}$} & .38 & \multicolumn{2}{|c|}{ Adjusted $R^{2}$} & .40 \\
\hline
\end{tabular}

Note: ${ }^{*} p<.001,{ }^{* *} p<.005,{ }^{* \star *} p<.01$

trinsic satisfaction from helping. In contrast, the Green citizen category is predicted by intrinsic satisfaction from frugality and being connected to nature.

\section{Discussion}

The findings of this study suggest that green consumerism and green citizenship are distinctly different behavioral patterns. Furthermore, each behavior pattern is 
supported by different psychological constructs. Green consumerism is predicted by holding pro-environmental attitudes and from the intrinsic motivation derived from social helping and sharing behaviors. Green citizenship, in dramatic contrast, is predicted by the intrinsic motivation derived from pursuing frugal activities and from feelings of being connected to nature. One set of constructs, those measuring prospecting the future, was not found predictive of either green consumer or green citizen behavior. It is possible that prospection is measuring the behavior change stages of contemplation and preparation (Prochaska and DiClemente 1982) and that this study's respondents were well beyond those early stages of change.

Interestingly, the background demographic measures do not differentiate green consumers from green citizens, as the ones measured in the present study did not emerge as significant predictors of either. Instead, the results here suggest that in seeking to promote green citizenship or green consumerism, policy prescriptions should turn their focus to leveraging psychological-based constructs. The link between pro-environmental attitudes and green consumerism is commonly reported in the conservation behavior literature (Abrahamse et al. 2005; De Young 1993). This link also is consistent with the realization that, within a consumer society, it would be deemed appropriate to use education, marketing, and social norm management to put pro-environmental attitudes into practice through the buying of green products. The predictive relationship between deriving intrinsic satisfaction from helping/sharing behaviors and green consumerism also might be understood in light of the fact that within modern consumer society a major means of improving the well-being of others is through the sharing of consumer products, physical resources, and one's time (e.g., giving canned goods to food pantries, seasonal donations of clothing and toys, community volunteering).

These findings parallel the current way of crafting a sustainable society. The decades-long mainstream approach has been to focus almost all of the attention on providing people with green consumer choices (e.g., buying green products, shopping at organic stores, using green appliances at home) while ignoring opportunities to encourage green citizenship. Very few efforts exist that seek to promote frugality or non-marketplace, non-material aspects of a sustainable existence. Indeed, except for a small subset of the population in industrial societies, resourceful patterns of behavior are not those toward which people typically strive. Thus, while the need for frugality may be valued in the abstract and eventually be necessary for communities to thrive, very few individuals within industrial society presently practice it. In fact, this once-commonplace virtue (Nash 1998) has become much maligned and dismissed as old-fashioned. It seems likely that any motivation to be frugal is 
presently overwhelmed by the motivation to be comfortable while doing one's part for the planet through green consumption.

Nonetheless, the research findings are unequivocal regarding resourceful behavior. Frugality is tightly linked with pro-environmental behaviors (Corral-Verdugo et al. 2011). And while frugality most certainly underlies pro-environmental behaviors, its pursuit also has been found to contribute both to present and future wellbeing (Kaida and Kaida 2016). Additionally, frugality will be necessary to significantly lower absolute levels of consumption since, it turns out, other shorter-term responses (e.g., being thrifty, efficient) might save money for an individual but do not necessarily contribute to an overall reduction in consumption because such a focus often involves purchasing cheaper products that are not long-lasting (Evans 2011).

Taken together, the findings reported here suggest that those who identify as green citizens may be open to new, perhaps even radical, approaches to environmental stewardship that do not rely on consumer behaviors whatsoever. There may be a form of green citizenship that goes far beyond the conception of the ecological citizen. This would mesh nicely with Hayward's (2006) critique of Dobson's conceptualization of ecological citizenship. Hayward notes that there is nothing inherently ecological about the virtues of citizenship proposed by Dobson. By way of improving the concept of ecological citizenship, Hayward offers the virtue of resourcefulness, which involves the 'development and exercise of human capacities, and thus fulfills part of the substance of a good human life; it also eases pressure on finite natural phenomena that are needed as resources in (roughly) inverse proportion to resourcefulness" (Hayward 2006, 442). Interestingly, the shortcomings of ecological citizenship noted by Hayward are also absent from green consumerism. Yet Hayward's virtue of resourcefulness is present, at least in part, in green citizenship. That is, deriving satisfaction and mitigating environmental harm by acting frugally, seeking durability, and creatively reducing and/or reusing materials (De Young 1996; Ryan and Deci 2000).

We might be inclined to tolerate green consumerism since, as one might point out, it provides individuals with an initial gateway into increased pro-environmental awareness and action (Truelove et al. 2014). Yet, after many decades of conservation behavior research we have come to realize that the realities of all forms of materialism and consumerism are problematic. Green consumerism vastly underestimates the complexity of human nature and subverts a range of behavioral responses that are not only needed to effectively address society's environmental and resource dilemma, but are also more naturally aligned with human well-being and satisfaction. 
Though firmly entrenched in modern society, research reveals that material consumption may adversely affect humans' mental and physical wellbeing (Fredrickson et al. 2013; Jackson 2005). Encouragingly, the notion that individuals may live better while consuming less reflects shifting patterns in American public discourse in that many citizens are profoundly concerned about the negative social, economic and environmental externalities associated with consumption (Markowitz and Bowerman 2014; Schor 1999; Stafford, Taylor, and Houston 2001). Green citizenship offers multiple and necessary pathways for engagement that reflect the promise of advancing change through reduced consumption and pushing policy on the community and national scale. Greater or broader engagement outside of the consumer domain can achieve more.

It is important to note the limitations of our study. The sample was drawn from members of organizations with strong ties to environmental initiatives and who may, in turn, possess an advanced understanding of the intersection of consumption and environmental degradation. Therefore, we are unable to draw any generalizations to what may constitute or motivate green citizenship behavior among members of the general public. Nevertheless, insights here suggest that those intimately interested in and working in the field are differentially motivated to engage in each construct, though additional work should investigate how and to what extent members of the public understand and experience the notion of green citizenship. Additionally, the analysis was correlational, which limits the ability to identify the psychological constructs that cause green citizenship.

\section{Conclusion}

By examining how core psychological factors relate to the adoption of green citizen versus green consumer behaviors, the present research provides an initial profile of green citizenship. Among this study's sample of environmentally engaged individuals, green citizens were distinctly motivated by their connection to nature and the intrinsic satisfaction derived from the frugal use of resources. Green consumers, in contrast, were driven by pro-environmental attitudes and satisfaction derived from helping and sharing with others. This research offers an alternative pathway to environmental stewardship, one that focuses on citizen action beyond that of merely being greener and leaner. Future research could further examine the characteristics of green citizens and, in particular, how to more effectively motivate such citizenship from within our industrial consumer society. 


\section{References}

Abrahamse, Wokje, Linda Steg, Charles Vlek, and Talib Rothengatter. "A Review of Intervention Studies Aimed at Household Energy Conservation." Journal of Environmental Psychology 25, no. 3 (2005): 273-291.

Alfredsson, Eva C. “'Green' consumption—no solution for climate change.” Energy 29, no. 4

(2004): 513-524.

Ajzen, Icek. "The Theory of Planned Behavior." Organizational Behavior and Human Decision Processes 50, no. 2 (1991): 179-211.

Bamberg, Sebastian, and Guido Möser. "Twenty Years After Hines, Hungerford, and Tomera: A New Meta-Analysis of Psycho-Social Determinants of Pro-Environmental Behaviour." Journal of Environmental Psychology 27, no. 1 (2007): 14-25.

Bamberg, Sebastian, and Peter Schmidt. "Incentives, Morality, or Habit? Predicting Students' Car Use for University Routes with the Models of Ajzen, Schwartz, and Triandis." Environment and Behavior 35, no. 2 (2003): 264-285.

Brown, Kirk Warren, and Tim Kasser. "Are Psychological and Ecological Well-Being Compatible? The Role of Values, Mindfulness, and Lifestyle." Social Indicators Research 74, no. 2 (2005): 349-368.

Christoff, Peter. "Ecological Citizens and Ecologically Guided Democracy." In Democracy and Green Political Thought: Sustainability, Rights and Citizenship, eds. Brian Doherty and Marius de Geus (London, UK: Routledge, 1996), 151-169.

Cialdini, Robert B. "Crafting Normative Messages to Protect the Environment." Current Directions In Psychological Science 12, no. 4 (2003): 105-109.

Clayton, Susan, Patrick Devine-Wright, Janet Swim, Mirilia Bonnes, Linda Steg, Lorraine Whitmarsh, and Amanda Carrico. "Expanding the role for psychology in addressing environmental challenges." American Psychologist 71, no. 3 (2016): 199.

Cohen, Claude, Manfred Lenzen, and Roberto Schaeffer. "Energy Requirements of Households in Brazil." Energy Policy 33, no. 4 (2005): 555-562.

Cornelissen, Gert, Michael R. Bashshur, Julian Rode, and Marc Le Menestrel. "Rules or Consequences? The Role of Ethical Mind-Sets in Moral Dynamics.” Psychological Science 24, no. 4 (2013): 482-488.

Corral-Verdugo, Victor, José Mireles-Acosta, Cesar Tapia-Fonllem, and Blanca Fraijo-Sing. "Happiness as Correlate of Sustainable Behavior: A Study of Pro-Ecological, Frugal, Equitable, and Altruistic Actions that Promote Subjective Wellbeing." Human Ecology Review 18, no. 2 (2011): 95-104.

Cronbach, Lee J. "Coefficient Alpha and the Internal Structure of Tests." Psychometrika 16, no. 3 (1951): 297-334.

Davidson, Debra J., and Wiluam R. Freudenburg. "Gender and Environmental Risk Concerns a Review and Analysis of Available Research." Environment and Behavior 28, no. 3 (1996): 302339.

De Young, Raymond. "Some Behavioral Aspects of Energy Descent: How a Biophysical Psychology Might Help People Transition Through the Lean Times Ahead." Frontiers in Psychology 5 (2014).

De Young, Raymond. "Some Psychological Aspects of Reduced Consumption Behavior the Role 
of Intrinsic Satisfaction and Competence Motivation.” Environment and Behavior 28, no. 3 (1996): 358-409.

De Young, Raymond. "Changing Behavior and Making It Stick: The Conceptualization and Management of Conservation Behavior: Environment and Behavior 25, no. 3 (1993): 485-505.

De Young, Raymond. "Some Psychological Aspects of Living Lightly: Desired Lifestyle Patterns and Conservation Behavior." Journal of Environmental Systems 20, no. 3 (1990): 215-227.

Dean, Hartley. "Green Citizenship." Social Policy \& Administration 35, no. 5 (2001): 490-505.

Dietz, Thomas, Eugene A. Rosa, and Richard York. "Driving the Human Ecological Footprint." Frontiers in Ecology and the Environment 5, no. 1 (2007): 13-18.

Dobson, Andrew. Citizenship and the Environment. (Oxford: Oxford University Press, 2003).

Dobson, Andrew. "Ecological Citizenship: A Defense." Environmental Politics 15, no. 03 (2006): 447-451.

Dunlap, Riley E., Kent D. Van Liere, Angela G. Mertig, and Robert Emmet Jones. "New Trends in Measuring Environmental Attitudes: Measuring Endorsement of the New Ecological Paradigm: A Revised NEP Scale.” Journal of Social Issues 56, no. 3 (2000): 425-442.

Ehrlich, Paul R. and Holdren, John P. "Impact of Population Growth." Science, American Association for the Advancement of Science. 171 no. 3977 (1971): 1212-1217.

Engel, Joan Gibb. "Who Are Democratic Ecological Citizens?" Hastings Center Report 28, no. 6 (1998): s23-s30.

Evans, David. "Thrifty, Green or Frugal: Reflections on Sustainable Consumption in a Changing Economic Climate." Geoforum 42, no. 5 (2011): 550-557.

Fredrickson, Barbara L., Karen M. Grewen, Kimberly A. Coffey, Sara B. Algoe, Ann M. Firestine, Jesusa MG Arevalo, Jeffrey Ma, and Steven W. Cole. "A Functional Genomic Perspective on Human Well-Being." Proceedings of the National Academy of Sciences 110, no. 33 (2013): 13684-13689.

Fishbein, Martin, and Icek Ajzen. "Belief, Attitude, Intention, and Behavior: An Introduction to Theory and Research." Philosophy and Rhetoric 10 no. 2 (1977):130-132.

Gardner, Gerald T., and Paul C. Stern. Environmental problems and human behavior. Allyn \& Bacon, 1996.

Gilg, Andrew, Stewart Barr, and Nicholas Ford. "Green consumption or sustainable lifestyles? Identifying the sustainable consumer." Futures 37, no. 6 (2005): 481-504.

Guckian, Meaghan L., Erin M. Hamilton, and Raymond De Young. "Cognitive Mapping as Participatory Engagement in Social Science Research on Sustainability." Under Review. (2017).

Hamari, Juho, Mimmi Sjöklint, and Antti Ukkonen. "The Sharing Economy: Why People Participate in Collaborative Consumption." Journal of the Association for Information Science and Technology 67 no. 9 (2015).

Hamilton, Erin M., Meaghan L. Guckian, and Raymond De Young. "Living Well and Living Green: Participant Conceptualizations of Green Citizenship”. Under Review. (2017).

Harmaala, Minna-Maari. "The Sharing City as a Platform for a More Sustainable City Environment?" International Journal of Environment and Health 7, no. 4 (2015): 309-328.

Harland, Paul, Henk Staats, and Henk AM Wilke. "Explaining Proenvironmental Intention and Behavior by Personal Norms and the Theory of Planned Behavior." Journal of Applied Social Psychology 29, no. 12 (1999): 2505-2528.

Hayward, Tim. "Ecological Citizenship: Justice, Rights and the Virtue of Resourcefulness." Environmental Politics 15, no. 03 (2006): 435-446. 
Heinrichs, Harald. "Sharing Economy: A Potential New Pathway to Sustainability." GAIAEcological Perspectives for Science and Society 22, no. 4 (2013): 228-231.

Horton, Dave. "Demonstrating Environmental Citizenship? A Study of Everyday Life Among Green Activists." In Environmental Citizenship, editors Andrew Dobson and Derek Bell (Cambridge, MA: MIT Press, 2006): 127-150.

Jackson, Tim. "Live Better by Consuming Less?: Is There a 'Double Dividend' in Sustainable Consumption?” Journal of Industrial Ecology 9, no. 1-2 (2005): 19-36.

Jackson, Tim. Prosperity without growth: The transition to a sustain-able economy. (London, UK: Sustainable Development Commission, 2009).

Jagers, Sverker C. "In Search of the Ecological Citizen." Environmental Politics 18, no. 1 (2009): 18-36.

Jagers, Sverker C., Johan Martinsson, and Simon Matti. "Ecological Citizenship: A Driver of ProEnvironmental Behaviour?” Environmental Politics 23, no. 3 (2014): 434-453.

Jagers, Sverker C., and Simon Matti. "Ecological Citizens: Identifying Values and Beliefs that Support Individual Environmental Responsibility Among Swedes.” Sustainability 2, no. 4 (2010): $1055-1079$.

Kaida, Naoko, and Kosuke Kaida. "Pro-Environmental Behavior Correlates with Present and Future Subjective Well-Being." Environment, Development and Sustainability 18, no. 1 (2016): 111-127.

Kaplan, Rachel. "A Strategy for Dimensional Analysis." Man-environment interactions in Environmental Design Research Association Proceedings, Part 9 (Oklahoma City, OK: Environmental Design Research Association, 1974), 66-68.

Kaplan, Stephen, and Rachel Kaplan. "Creating a Larger Role for Environmental Psychology: The Reasonable Person Model as an Integrative Framework." Journal of Environmental Psychology 29, no. 3 (2009): 329-339.

Kasser, Tim, Steve Cohn, Allen D. Kanner, and Richard M. Ryan. "Some Costs of American Corporate Capitalism: A Psychological Exploration of Value and Goal Conflicts." Psychological Inquiry 18, no. 1 (2007): 1-22.

Kasser, Tim, and Richard M. Ryan. "Further Examining the American Dream: Differential Correlates of Intrinsic and Extrinsic Goals." Personality and social psychology bulletin 22, no. 3 (1996): 280-287.

Kollmuss, Anja, and Julian Agyeman. "Mind the Gap: Why Do People Act Environmentally and What Are the Barriers to Pro-Environmental Behavior?" Environmental education research 8, no. 3 (2002): 239-260.

March, James G. A Primer On Decision Making: How Decisions Happen. (New York, NY: The Free Press, 1994).

Markowitz, Ezra M., and Tom Bowerman. "How Much Is Enough? Examining the Public's Beliefs about Consumption." Analyses of Social Issues and Public Policy 12, no. 1 (2012): 167-189.

Markowitz, Ezra M., Lewis R. Goldberg, Michael C. Ashton, and Kibeom Lee. "Profiling the 'Pro-Environmental Individual': A Personality Perspective." Journal of Personality 80, no. 1 (2012): 81-111.

Martin, Chris J. "The Sharing Economy: A Pathway to Sustainability or a Nightmarish Form of Neoliberal Capitalism?” Ecological Economics 121 (2016): 149-159.

Mayer, F. Stephan, and Cynthia McPherson Frantz. "The Connectedness To Nature Scale: A Measure Of Individuals' Feeling In Community With Nature.” Journal of Environmental Psychology 24, no. 4 (2004): 503-515. 
Munksgaard, Jesper, Mette Wier, Manfred Lenzen, and Christopher Dey. "Using Input-Output Analysis to Measure the Environmental Pressure of Consumption at Different Spatial Levels." Journal of Industrial Ecology 9, no. 1-2 (2005): 169-185.

Nash, J. A. "On the Subversive Virtue: Frugality" in Ethics of Consumption: The Good Life,

Justice and Global Stewardship, editors David. A. Crocker and Tobey Linden (Lanham: Rowman \& Littlefield Publishers, 1998): 416-436.

Nisbet, Elizabeth K., John M. Zelenski, and Steven A. Murphy. "The Nature Relatedness Scale: Linking Individuals' Connection with Nature to Environmental Concern and Behavior." Environment and Behavior (2008).

Nunnally, Jum. Psychometric Theory. (New York: McGraw-Hill, 1978).

Pike, Cara, Bob Doppelt, and Meredith Herr. "Climate Communications and Behavior Change: A Guide for Practitioners." Climate Leadership Initiative. (2010).

Prochaska, James O., and Carlo C. DiClemente. "Transtheoretical Therapy: Toward a More Integrative Model of Change.” Psychotherapy: Theory, Research \& Practice 19, no. 3 (1982): 276.

Ryan, Richard M., and Edward L. Deci. "Self-Determination Theory and the Facilitation of Intrinsic Motivation, Social Development, and Well-Being." American Psychologist 55, no. 1 (2000): 68.

Ryan, Robert L., and Robert E. Grese. "Urban Volunteers and the Environment: Forest and Prairie Restoration” in Urban Place, editor Peggy F. Bartlett. (Cambridge, MA: MIT Press, 2005).

Ryan, Robert L., Rachel Kaplan, and Robert E. Grese. "Predicting Volunteer Commitment in Environmental Stewardship Programmes." Journal of Environmental Planning and Management 44, no. 5 (2001): 629-648.

Schor Juliet, B. The Overspent American: Why We Want What We Don't Need. (New York, NY: HapperCollins, 1998).

Schuitema, Geertje, Linda Steg, and Sonja Forward. "Explaining differences in acceptability before and acceptance after the implementation of a congestion charge in Stockholm." Transportation Research Part A: Policy and Practice 44, no. 2 (2010): 99-109.

Schultz, P. Wesley. "The Structure of Environmental Concern: Concern for Self, Other People, and the Biosphere." Journal of Environmental Psychology 21, no. 4 (2001): 327-339.

Seyfang, Gill. "Ecological Citizenship and Sustainable Consumption: Examining Local Organic Food Networks." Journal of Rural Studies 22, no. 4 (2006): 383-395.

Shove, Elizabeth. "Beyond the ABC: climate change policy and theories of social change." Environment and planning $A$ 42, no. 6 (2010): 1273-1285.

Stanford, Jim, Lance Taylor, and Ellen Houston. Power, employment, and accumulation: social structures in economic theory and practice. (New York, NY: Sharpe, 2001).

Stern, Paul C. "Towards a Coherent Theory of Environmentally Significant Behavior." Journal Of Social Issues, 56. (2000).

Stern, Paul C., Linda Kalof, Thomas Dietz, and Gregory A. Guagnano. "Values, Beliefs, and Proenvironmental Action: Attitude Formation Toward Emergent Attitude Objects." Journal of Applied Social Psychology 25, no. 18 (1995): 1611-1636.

Stern, Paul C., Thomas Dietz, Troy D. Abel, Gregory A. Guagnano, and Linda Kalof. "A ValueBelief-Norm Theory of Support for Social Movements: The Case of Environmentalism.” Human Ecology Review 6, no. 2 (1999): 81-97.

Thøgersen, John, and Folke Ölander. "To What Degree Are Environmentally Beneficial Choices Reflective of a General Conservation Stance?” Environment and Behavior 38, no. 4 (2006): 550-569. 
Thomas, Gregory Owen, Wouter Poortinga, and Elena Sautkina. "The Welsh Single-Use Carrier Bag Charge and behavioural spillover." Journal of Environmental Psychology 47 (2016): 126135.

Truelove, Heather Barnes, Amanda R. Carrico, Elke U. Weber, Kaitlin Toner Raimi, and Michael P. Vandenbergh. "Positive and Negative Spillover of Pro-Environmental Behavior: An Integrative Review and Theoretical Framework." Global Environmental Change 29 (2014): 127-138.

Van Steenbergen, Bart. "Towards a Global Ecological Citizen." The condition of citizenship, ed. Bart Van Steenberger (London; Thousand Oaks; New Delhi: SAGE Publications, 1994): 141-152.

Weber, Elke U., Daniel R. Ames, and Ann-Renée Blais. "'How Do I Choose Thee? Let Me Count the Ways': A Textual Analysis of Similarities and Differences in Modes Of Decision-Making in China and the United States." Management And Organization Review 1, no. 1 (2005): 87-118.

Weber, Elke U., and Patricia G. Lindemann. "From Intuition to Analysis: Making Decisions with Our Head, Our Heart, or by the Book." Intuition in judgment and decision making, eds Plessner, Henning, Cornelia Betsch, and Tilmann Betsch (Mahwah, NJ: Erlbaum, 2007): 191-208.

Weiss, Richard. The American myth of success: From Horatio Alger to Norman Vincent Peale. (University of Illinois Press, 1969).

Wolf, Johanna, Katrina Brown, and Declan Conway. "Ecological Citizenship and Climate Change: Perceptions and Practice.” Environmental Politics 18, no. 4 (2009): 503-521. 